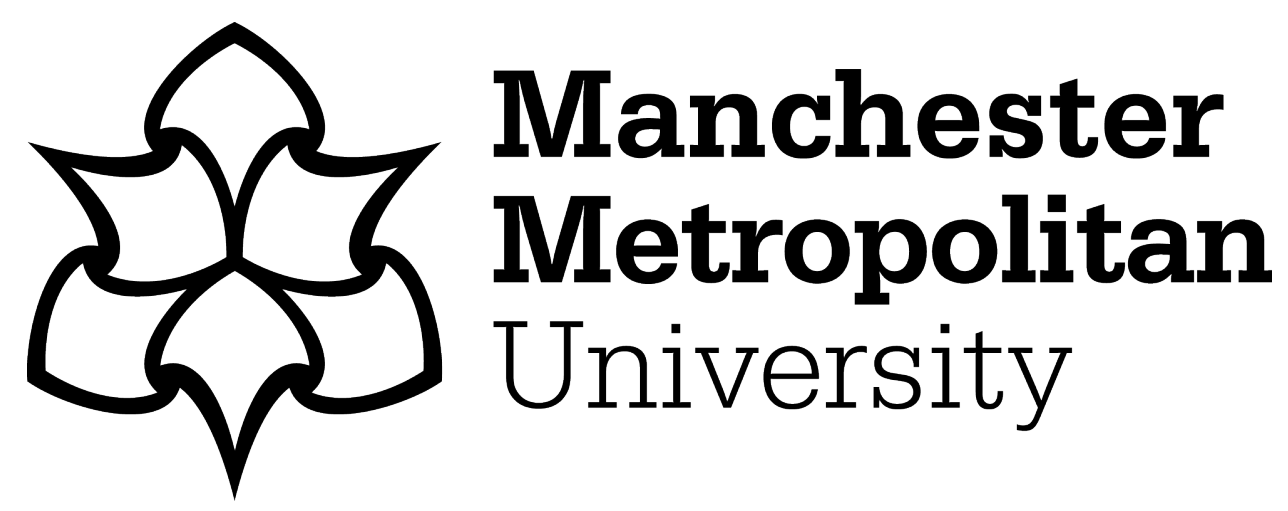

Olivero, J, Fa, JE, Farfán, MA, Márquez, AL, Vargas, JM, Real, R and Nasi, $R$ (2016) Protected African rainforest mammals and climate change. African Journal of Ecology, 54 (3). pp. 392-397. ISSN 0141-6707

Downloaded from: https://e-space.mmu.ac.uk/611702/

Version: Accepted Version

Publisher: Wiley

DOI: https://doi.org/10.1111/aje.12313

Please cite the published version 
African Journal of Ecology, Short Communications, IN PRESS

\section{Protected African rainforest mammals and climate change}

Jesús Olivero ${ }^{1}$, John E. Fa ${ }^{2,3^{*}}$, Miguel A. Farfán ${ }^{1,4}$, Ana L. Márquez ${ }^{1}$, Juan M. Vargas ${ }^{1}$, Raimundo R. Real ${ }^{1}$ and Robert Nasi ${ }^{3}$

${ }^{1}$ Universidad de Málaga, Grupo de Biogeografía, Diversidad y Conservación, Departamento de Biología Animal, Facultad de Ciencias, Campus de Teatinos s/n, 29071 Málaga, Spain, ${ }^{2}$ Division of Biology and Conservation Ecology, School of Science and the Environment, Manchester Metropolitan University, Manchester MI

$5 G D, U K,{ }^{3}$ Center for International Forestry Research (CIFOR), CIFOR Headquarters, Bogor 16115, Indonesia. ${ }^{4}$ BioGea Consultores, C/Navarro Ledesma 243, Portal 4- $3^{\circ} \mathrm{C}$, 29010 Málaga, Spain

\section{Introduction}

Well-governed and effectively managed national parks, game reserves, wilderness areas and other legally established protected areas (PAs) provide a wide range of social, environmental and economic benefits worldwide (Ervin et al., 2010). However, current reserve networks may be inadequate to protect sufficient amounts of biodiversity because of lack of representativeness of species and landscapes. Moreover, because of 
their static nature, species may be driven out of reserves (Araújo et al., 2004), or may become extinct if unable to disperse to other suitable areas (Thuiller et al., 2005).

The Central African forest region is globally outstanding (Blom et al., 2004). PAs here cover over $12 \%$ of the total forest area (FAO, 2011). But, their effectiveness in protecting biodiversity over the longer term is affected by increasing human pressures (Fa et al., 2002) and vulnerability to 21 st century human-induced climatic change (CC) (Velarde et al., 2005).

Studies aimed at safeguarding the existing sub-Saharan African vertebrate diversity have focused, often separately, on understanding the effectiveness of the existing PA networks on species (e.g. birds: Muriuki et al., 1997; mammals: Fjeldså et al., 2004) or on how potential exposure to CC impact these (García et al., 2012). Only Thuiller et al. (2006) evaluated whether national parks throughout Africa (at $0.16^{\circ}$ resolution) will meet their mandate under future $\mathrm{CC}$ and land transformation conditions. Although these published projections are useful, new CC scenarios have been proposed (IPCC, 2013), and recent analyses of the mammal diversity in Africa (Fa et al., 2014) allow for assessments at higher spatial resolutions. Here, we present, for the first-time, analyses at $0.1^{\circ}$ resolution, that examine the potential impact of $\mathrm{CC}$ on the protection of forest mammals within the Rainforest Biotic Zone (RBZ) in Central Africa.

\section{Methods}

\section{Study area}

The study area covered the limits of the RBZ (Kingdon et al., 2013); $10^{\circ} \mathrm{N}, 10.5^{\circ} \mathrm{S}, 8^{\circ} \mathrm{E}$ and $36^{\circ} \mathrm{E}$. The region comprises the second largest and best-preserved area of contiguous tropical rainforest in the world, but evergreen/deciduous broadleaf forests and woody savannas, as well savanna and cropland-natural vegetation mosaic are also found (Friedl et al. 2010). 
All or large parts of the Democratic Republic of the Congo, the Republic of the Congo, Central African Republic, Cameroon, Gabon, Equatorial Guinea, Uganda, Rwanda, Burundi, Angola, Nigeria, Tanzania and Sudan are represented (Fig. 1). Species data

In total we used data for 165 mammals (11 Orders), $>1 \mathrm{~kg}$ body mass and which were hunted for bushmeat, accounting for almost all land mammals in the region (Fa et al. (2014). We introduced susceptibility to hunting in our models as an additional layer of vulnerability to extinction beyond CC. For all species, we mapped their current and future distributions (at $0.1^{\circ}$ resolution) by using favourability-function models (Acevedo \& Real, 2012).

Determining hot spots and weak spots

We defined geographical hot spots as areas of high diversity, and weak spots as high diversity regions of special hunting vulnerability for wildlife (Fa et al., 2014). We employed hot spots and weak spots here, as described in Fa et al. (2014).

Mammalian richness was measured employing two surrogate indices based on accumulating favourability values obtained, for every species in every locality, through distribution modeling (Real et al., 2006; Estrada et al., 2008). Favourability models (Real et al., 2006; Acevedo \& Real, 2012) can distinguish between localities whose environmental conditions favour the species' presence and localities where conditions are detrimental for the species, independently of the effect of the species' prevalence within the study area (Acevedo \& Real, 2012). This allows for model combinations using fuzzy logic (Estrada et al., 2008; Barbosa \& Real, 2012).

Presences and absences of the 165 study species were recorded in $1^{\circ}$ resolution cells, using IUCN range maps (IUCN, 2014); this is the maximum spatial resolution at which extent of occurrence maps are suitable for distribution modeling (Hurlbert \& Jetz, 
2007). Favourability models were trained for the entire African continent, considering 27 predictor variables describing topography, hydrography, climate, land cover/use and other anthropogenic pressures (see Appendices S2 and S3 in Fa et al., 2014); we also accounted for the impact of dispersal barriers, geological history and biotic interactions through the trend surface approach (Legendre, 1993; Fa et al., 2014).

Favourability models were projected to a $0.1^{\circ}$ resolution grid using the direct downscaling method (Bombi \& d'Amen, 2012). Finally, only favourability values where species are known to occur according to IUCN were retained. In this step of the procedure, the distribution areas for subspecies were considered separately.

The diversity index used to define hot spots was the Accumulated Favourability $\left(A F_{j}\right)$, calculated by summing the favourability $\left(F_{i}\right)$ value of all $i$ taxa in each $j$ cell in the study area:

$$
A F_{j}=\sum F_{i}
$$

Hot spots were then defined by selecting the highest $5 \%$ of $A F_{j}$ values. This cutoff matches the proportion of the study area that is currently covered by PA.

The diversity index used to define weak spots was the Unsustainable Accumulated Favourability $\left(U A F_{j}\right)$, whose calculation is similar to that of $A F_{j}$ with the exception that each taxon's favourability value was weighted according to a measure of the taxon's vulnerability. For this weighting, we used the index of Potential Hunting Sustainability $(P H S)$ that is the taxon's potential resilience to hunting according to ecological traits that are linked with extinction proneness (Cardillo et al., 2005; Fa et al., 2014). PHS was built according to the restrictive approach in Fa et al. (2014), which is based on a combination of four ecological traits: population density, habitat breadth, 
rarity and vulnerability. A detailed description of the procedure to calculate $P H S$ is found in Fa et al. (2014). $U A F_{j}$ was finally computed as follows:

$$
U A F_{j}=\sum\left[F_{i} \times\left(1-P H S_{i}\right)\right]
$$

Weak spots were then defined by selecting the highest $5 \%$ of $U A F_{j}$ values. Hot spot and weak spot projection to future

For each species/subspecies in each cell, future favourability values for 2050 were obtained by replacing present values with future values in the variables predicting favourability. Only climate, intact forest and rural population were considered to have changed by 2050 , whereas the rest of variables were assumed not to vary significantly. In this way, for each taxon distribution, the relevance of predicted changes in climate, forest cover and population was proportional to the relative importance of these factors among the variables defining the model. Conservatism regarding expected responses of species to environmental changes was assumed, which is reasonable regarding predictions referred to less than 45 years from present.

The two most extreme greenhouse gas scenarios currently proposed by IPCC (2013) have been considered: RCP26 (optimistic) and RCP85 (pessimistic). Therefore, part of the uncertainty unavoidably linked to predictions based on climate forecasting was taken into account (Real et al., 2010). Climate future values were downloaded from WorldClim (http://www.worldclim.org/CMIP5). We chose forecasts based on the HADGEM2-ES global circulation model (GCM), because it has been proved to match the climatology in both tropics and extra-tropics (Collins et al., 2008; Brands et al., 2013). 
The World Intact Forest Landscapes (IFL) 2000 map (Potapov et al., 2008) has been updated for the period 2006-2011 (http://www.intactforests.org). We have used the changes observed between 2000 and 2010 to model a forecast for 2050 using Markov chain analysis (Deadman \& Brown, 1993), under the assumption that current geographical trends in deforestation are applicable to the following decades. We used IDRISI Selva software for this purpose (Eastman, 2012).

Future values of rural population density for 2050 were approximated using World Population Prospects: The 2012 Revision (United Nations, 2013). The medium scenario population growth estimates, which take the effects of AIDS into consideration (Musters et al., 2000), were used. A growth rate was then calculated for every country by dividing national population densities forecasted for 2050 with national densities in 2010. Values in the raster map for rural population density (Fa et al., 2014) were finally multiplied by the corresponding national rates.

In order to estimate $A F_{j}$ and $U A F_{j}$ values for 2050, future favourability maps for every species/subspecies were integrated in equations 1 and 2. Finally, the same diversity thresholds as for present hot spots and weak spots delimited future hot spots and weak spots.

\section{Diversity-based assessment of protection networks}

We assessed the suitability of the network of protected sites recorded at the World Database on Protected Areas (WDPA) (UNEP-WCMC, 2012), as a management tool for contributing to the conservation of high-diversity areas for hunted mammals (Fig 1). The goal of a network of protected sites is to ensure that all ecosystems and areas rich in species diversity are represented adequately in biodiversity management areas (Scott et al., 1993). Other criteria, such as representativeness (Margules, 1986), are the focus of ongoing works. 
Only sites at the WDPA defined as geographically bounded polygons, and subject to legal protection (excluding Ramsar sites since these have no legal denomination) were considered. We then calculated the proportion of the surface area in hot spots and weak spots included in a protected site. This operation was repeated using the future geographical limits forecasted for both hot spots and weak spots.

\section{Results and discussion}

Hot spots and weak spots significantly overlapped (97.1\%), occupying substantial areas north of the Congo River (Fig. 2), as proposed by Fjeldså et al. (2004) for the allmammals diversity analyses. But, the area occupied could decrease by $21.1-29.5 \%$ for hot spots (Fig. 2A), or by $23.4-32.8 \%$ for weak spots (Fig. 2B) depending on whether the most optimistic (RCP26) or the most pessimist emission scenario (RCP85) was considered. This would largely affect a north-to-south corridor along the western part of the study region.

Only $15.1 \%$ of hot spots were included in the current PA network; a percentage that could increase $0.8-1.3 \%$ by $2050(15.9 \%-16.4 \%$, depending on the gas emission scenario chosen), as a result of hot spots shrinking principally outside PAs. Similarly, $16.4 \%$ of weak spots were included in the PA network, and expected to increase $0.9-$ $2.0 \%$ by $2050(17.3 \%-18.4 \%)$. Our finding that the percentage PA within hot and weak spots would increase by 2050 indicates that the current PA network includes favourable conditions that allow species to persist after a potential retraction of rainforests due to CC.

In this paper, we focused exclusively on understanding the fate of significant mammalian richness and vulnerability areas in Central Africa. We showed that only a relatively small number of PAs lie within their boundaries; $84.9 \%$ of hot spots and $83.7 \%$ of weak spots remain unprotected. Thus, protection of hot spots and weak spots 
must, in our estimation, become an important conservation commitment given that these species blocks are probable centres of expansion in future CC scenarios. In fact, our hot spots and weak spots directly correspond to the 'Cameroon-Gabon 'Atlantic Rainforest Refuge' and the 'Central African Lowland Refuge', respectively; areas that during former forest reduction periods retained source populations of many mammals (Morley \& Kingdon, 2013).

Although we argue that conservationists should not concentrate exclusively on the preservation of hot spots and weak spots at the expense of addressing other important regions in Central Africa (Kareiva \& Marvier, 2003). In fact, areas outside our hot spots, such as the Cameroon Highlands (of very high mammalian endemism), would appear of significant conservation importance if a representativeness-based criterion were used (see Margules, 1986). These areas have also been highlighted as relatively unprotected by Fjeldså et al. (2004).

Conservation of Central Africa refuges must focus on supporting dispersal, colonisation and re-establishment processes, especially maintaining connectivity between high quality habitats spanning the distributional ranges of priority taxa, and restoring degraded zones. Finally, CC adaptation would require that sufficient area is maintained under adequate protection, to increase the resilience of existing populations and reduce species vulnerability to environmental changes (Bertzky et al., 2011).

\section{Acknowledgements}

This work is supported by the KnowFor (International Forestry Knowledge) initiative of the UK Department for International Development (UKAID). It is part of the CIFOR Bushmeat Research Initiative. A first version of the paper benefited from comments from N. Burgess. 


\section{References}

ACEVEDO P. \& REAL R. (2012) Favourability: concept, distinctive characteristics and potential usefulness. Naturwissenschaften 99, 515-522.

Araújo, M.B., Cabezas, M., Thuiller W., Hannah, L. \& Williams, P.H. (2004) Would climate change drive species out of reserves? An assessment of existing reserve-selection methods. Glob. Change. Biol. 10, 1618-1626.

BARBosA, A.M. \& REAL, R. (2012) Applying fuzzy logic to comparative distribution modelling: a case study with two sympatric amphibians. Scientific World Journal ID 428206

Bertzky M., Dickson B., Galt R., Glen, E., Harley, M., Hodgson, N., Keder, G., Lysenko, I., Pooley, M., Ravilious, C., Sajwad, T., Schiopu, R., De Soye, Y.\& TUCKER, G. (2011) Impacts of Climate Change and Selected Renewable Energy Infrastructures on EU Biodiversity and the Natura 2000 Network: Summary Report. European Commission and International Union for Conservation of Nature, Brussels.

BLOM, A. (2004) An estimate of the costs of an effective system of protected areas in the Niger Delta - Congo Basin Forest Region. Biodivers. Conserv. 13, 2661-2678.

BOMBI, P. \& D'AMEN, M. (2012) Scaling down distribution maps from atlas data: a test of different approaches with virtual species. J. Biogeogr. 39, 640-651.

Brands, S., Herrera, S., Fernández, J. \& Gutiérrez, J.M. (2013) How well do CMIP5 Earth System Models simulate present climate conditions in Europe and Africa? A performance comparison for the downscaling community. Clim. Dyn. 41, 803-817.

Cardillo, M., Mace, G.M., Jones, K.E., Bielby, J., BinindA-Emonds, O.R.P., Sechrest, W., Orme, C.D.L., Purvis, A. (2005) Multiple causes of high 
extinction risk in large mammal species. Science Express 10.1126/science. 1116030 .

Collins, W.J., Bellouin, N., Doutriaux-Boucher, M., Gedney, N., Hinton, T., Jones, C.D., Liddicoat, S., Martin, G., O’Connor, F., Rae, J., Senior, C., Totterdell, I., WoOdward, S., Reichler, T. \& Kim, J. (2008) Evaluation of the HadGEM2 model. Hadley Centre Technical Note 74. (Exeter: Met Office).

DEADMAN, P. \& BROWN, R.D. (1993) Modelling rural residential settlement patterns with cellular automata. J. Environ. Manage. 37, 147-160.

EASTMAN, J.R. (2012) IDRISI Selva. Clark University, Worcester, MA.

Ervin, J., Mulongoy, K. J., Lawrence, K., Game, E., ShePPard, D., Bridgewater, P., Bennett, G., GidDA, S.B. \& Bos, P. (2010) Making Protected Areas Relevant: A Guide to Integrating Protected Areas into Wider Landscapes, Seascapes and Sectoral Plans and Strategies. CBD Technical Series No. 44. Convention on Biological Diversity, Montreal.

EstradA, A., REAL, R. \& VARGAS, J.M. (2008) Using crisp and fuzzy modelling to identify favourability hotspots useful to perform gap analysis. Biodivers. Conserv. 17, 857-871.

Fa, J.E., Olivero, J., FArfán, M.A., MÁrquez, A.L., VArgas, J.M., ReAl, R. \& NASi, R. (2014) Integrating sustainable hunting in biodiversity protection in central Africa: hot spots, weak spots, and strong spots. PLoS ONE 9, e112367.

FA, J.E., PERES, C.A. \& MeEuWig, J. (2002) Bushmeat exploitation in tropical forests: an intercontinental comparison. Conserv. Biol. 16, 232-237.

FJeldSÅ J., BuRgess N.D., Blyth S. \& DE KLERK H.M. (2004) Where are the major gaps in the reserve network for Africa's mammals? Oryx 38, 17-25. 
Food And Agriculture Organisation (FAO) (2011) The State of Forests in the Amazon Basin, Congo Basin and Southeast Asia: A Report Prepared for the Summit of the three Rainforest Basins. Brazzaville, Republic of Congo, 31 May3 June, 2011, FAO, Rome.

Friedl, M. A., Sulla-Menashe, D., Tan, B., Schneider, A., Ramankutty, N., SiBLEY, A. \& HuANG, X. (2010) MODIS Collection 5 global land cover: Algorithm refinements and characterization of new datasets. Remote Sens. Environ. 114, 168-182.

García R.A., Burgess N.D., CABezA, M., RAhbeK, C. \& Araújo, M.B. (2012) Exploring consensus in 21 st century projections of climatically suitable areas for African vertebrates. Global Change Biol. 18, 1253-1269.

HurlBert, A.H. \& JeTZ, W. (2007) Species richness, hotspots, and the scale dependence of range maps in ecology and conservation. PNAS 104, 1338413389.

IPCC (2013) Climate Change 2013: The Physical Science Basis. Contribution of WGI to the 5th Assessment Report of the IPCC (Eds. Stocker, T.F., Qin, D., Plattner, G.-K., Tignor, M., Allen, S.K., Boschung, J., Nauels, A., Xia, Y., Bex, V., Midgley, P.M.). Cambridge University Press, Cambridge and New York.

IUCN (2014) IUCN red list of threatened species. Version 2012.1. Available: http://www.iucnredlist.org. Accessed 2015 July8

Kareiva, P. \& Marvier, M. (2003) Conserving biodiversity coldspots. Amer. Scien. 91, 344-351.

Kingdon, J., Happold, D., Hoffman, M., Butynski, T., Happold, M. \& Kalina, J. (Eds) (2013) Mammals of Africa: 6 Vols. (London: Bloomsbury Publishing). $3760 \mathrm{pp}$. 
LEGENDRE, P. (1993) Spatial autocorrelation: trouble or new paradigm? Ecology 74, 1659-1673.

Margules, C.R. (1986) Conservation Evaluation in Practice. In: Usher, M.B. (ed.)

Wildlife conservation evaluation: 298-314. Chapman \& Hall, London.

Márquez, A.L., Real, R., Olivero, J. \& EstradA, A. (1986) Combining climate with other influential factors for modeling the impact of climate change. Clim. Chang. 108, 135-157.

MORLEY, R.J. \& KINGDON J. (2013) Africa’s environmental and climatic past. In: Mammals of Africa. Volume I: Introductory Chapters and Afrotheria (Eds. J. Kingdon, D. HAPPOLD, T. BUtYNSKI et al.). Bloomsbury Publishing, London. Muriuki, J.N., De Klerk, H.M., Bennun, L.A., Crowe, T.M. \& VAnden Berge, E. (1997) Using patterns of distribution and diversity of Kenyan birds to select and prioritize areas for conservation. Biodivers. Conserv. 6, 191-210.

Musters, C.J.M., DE GRAAF, H.J. \& TER KeuRS, W.J. (2000) Can protected areas be expanded in Africa? Science 287, 1759-1760.

Potapov, P., Yaroshenko, A., Turubanova, S., Dubinin, M., Laestadius, L., Thies, C., Aksenov, D., Egorov, A., Yesipova, Y., Glushkov, I., KarPachevskiY, M., Kostikova, A., Manisha, A., Tsybikova, E. \& Zhuravleva, I. (2008) Mapping the World's Intact Forest Landscapes by Remote Sensing. Ecol, Soc. $13,51-66$.

REAL, R., BARBosA, A.M. \& VARGAS, J.M. (2006) Obtaining environmental favourability functions from logistic regression. Environ. Ecol. Stat. 12, 237245. 
Real, R., Márquez, A.L., Olivero, J. \& Estrada, A. (2010) Species distribution models in climate change scenarios are still not useful for informing policy planning: an uncertainty assessment using fuzzy logic. Ecography 33, 304-314.

Scott, J.M., DAvis, F., Csuti, B., Noss, R., Butterfield, B., Groves, C., Anderson, H., Caicco, S., D'Erchia, F., Edwards, JR. T.C., Ulliman, J. \& Wright, R.G. (1993) Gap Analysis: a geographic approach to protection of biological diversity. Wildlife Monogr. 123, 1-41.

Thuiller W., Lavorel, S., Araújo, M.B. Sykes, M.T. \& Prentice, I.C. (2005)

Climate change threats to plant diversity in Europe. PNAS 102, 8245-8250.

Thuiller, W., Broennimann, O., Hughes, G.O., Alkemade, J.R.M., Midgley, G.F., \& CORSI, F. (2006) Vulnerability of African mammals to anthropogenic climate change under conservative land transformation assumptions. Glob. Change Biol. $12,424-440$.

UNEP-WCMC (2012) Data Standards for the World Database on Protected Areas. UNEP-WCMC, Cambridge.

United Nations (2013) World Population Prospects: The 2012 Revision, Key Findings and Advance Tables. Working Paper No. ESA/P/WP.227. Department of Economic and Social Affairs, Population Division, New York.

Velarde, S.J., Malhi, Y., Moran, D., Wright, J. \& Hussain S (2005) Valuing the impacts of climate change on protected areas in Africa. Ecol. Econ. 53, 21-33. 


\section{FIGURE LEGENDS}

Fig. 1. Map of the study region showing the network of protected sites recorded at the World Database on Protected Areas (WDPA) (UNEP-WCMC, 2012) as pink polygons. Rainforests (dark green) and woody savannas (light green) are represented as in the MODIS Collection 5 global land cover (Friedl et al. 2010). The green line indicates the limits of the Rainforest Biotic Zone. National borders are represented as grey lines.

Fig 2. Distribution of hot spots and weak spots in the Rainforest Biotic Zone. a) Hot spots (high mammal-diversity areas) derived from the Accumulated Favourability $(A F)$ of 208 mammal taxa belonging to 165 species. b) Weak spots (areas with high diversity of mammals vulnerable to hunting) derived from the Unsustainable Accumulated Favourability $(U A F)$. Hot spots and weak spots are outlined in white. Color bars indicate present and predicted accumulated favourability values. Protected sites from the World Database on Protected Areas (WDPA) are outlined in dark brown. 


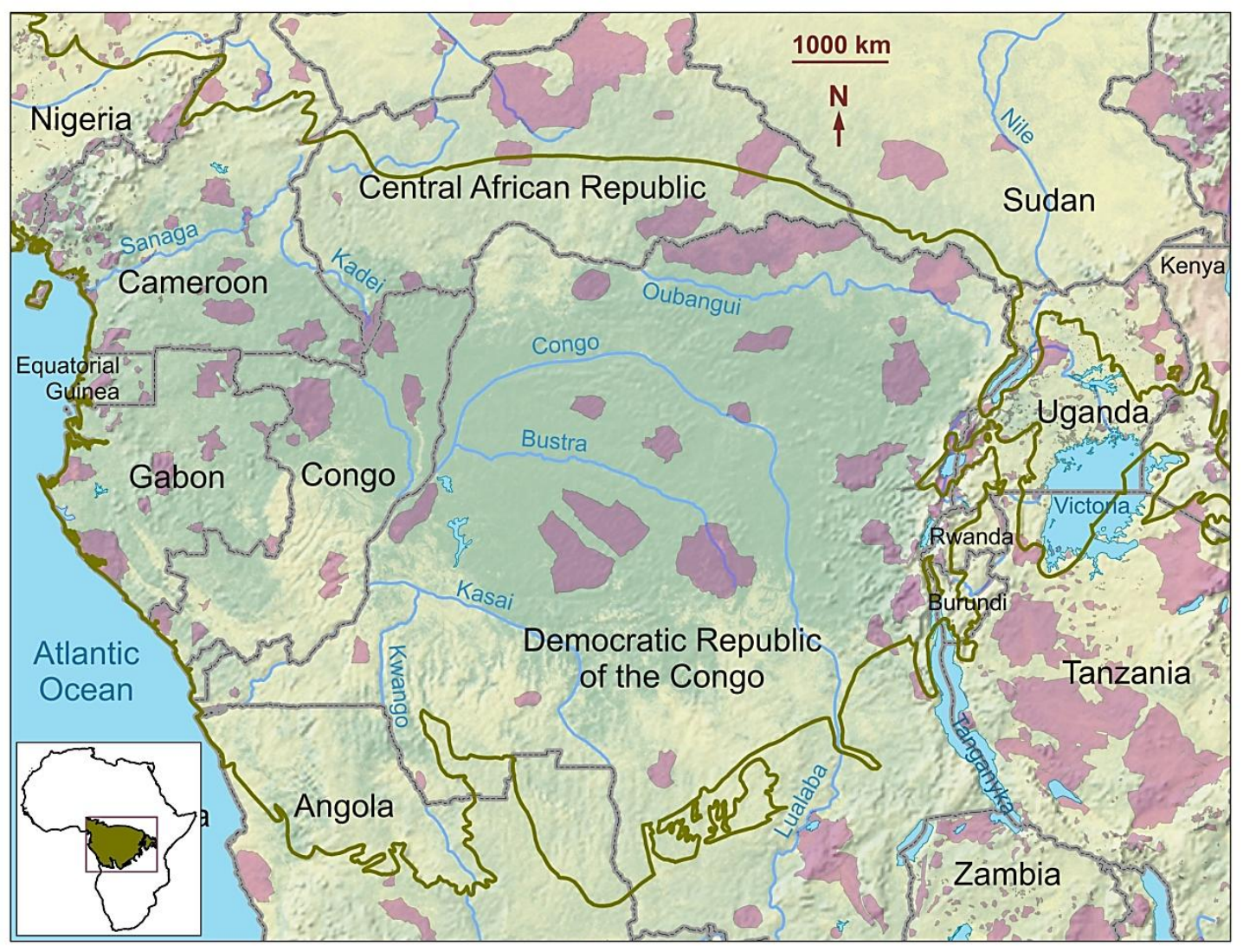




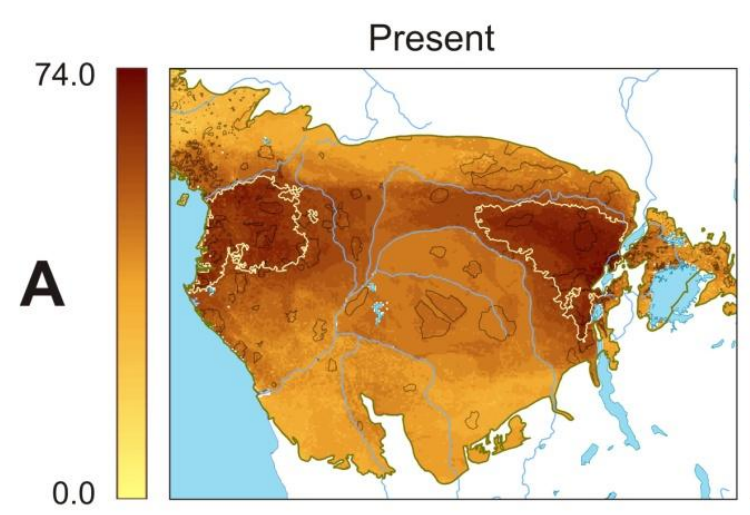

63.2

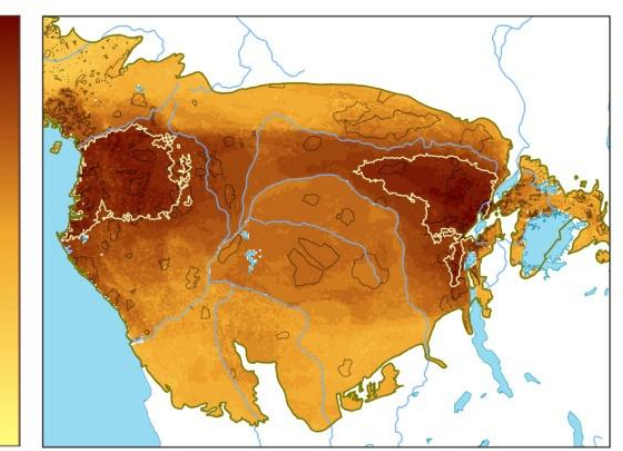

2050

RCP26 greenhouse

2050

RCP85 greenhouse gas scenario
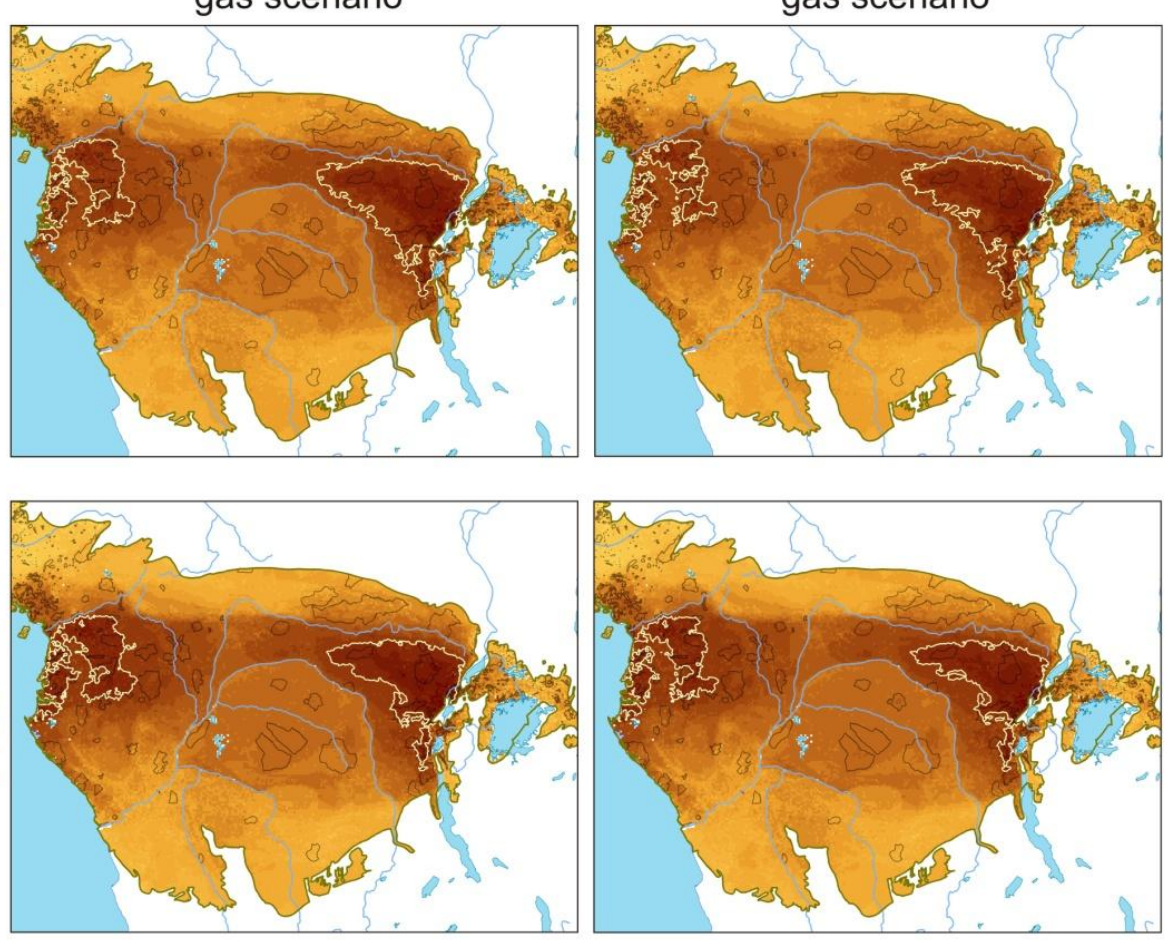